\title{
Characterization and Thermal Dehydration Kinetics of Highly Crystalline Mcallisterite, Synthesized at Low Temperatures
}

\author{
Emek Moroydor Derun and Fatma Tugce Senberber \\ Department of Chemical Engineering, Yildiz Technical University, 34210 Istanbul, Turkey \\ Correspondence should be addressed to Emek Moroydor Derun; moroydor@gmail.com
}

Received 18 November 2013; Accepted 19 January 2014; Published 25 February 2014

Academic Editors: A. L. R. Mercê and E. Mikuli

Copyright ( 2014 E. Moroydor Derun and F. T. Senberber. This is an open access article distributed under the Creative Commons Attribution License, which permits unrestricted use, distribution, and reproduction in any medium, provided the original work is properly cited.

\begin{abstract}
The hydrothermal synthesis of a mcallisterite $\left(\mathrm{Mg}_{2}\left(\mathrm{~B}_{6} \mathrm{O}_{7}(\mathrm{OH})_{6}\right)_{2} \cdot 9\left(\mathrm{H}_{2} \mathrm{O}\right)\right)$ mineral at low temperatures was characterized. For this purpose, several reaction temperatures $\left(0-70^{\circ} \mathrm{C}\right)$ and reaction times $(30-240 \mathrm{~min})$ were studied. Synthesized minerals were subjected to X-ray diffraction (XRD), fourier transform infrared (FT-IR), and Raman spectroscopies and scanning electron microscopy (SEM). Additionally, experimental analyses of boron trioxide $\left(\mathrm{B}_{2} \mathrm{O}_{3}\right)$ content and reaction yields were performed. Furthermore, thermal gravimetry and differential thermal analysis (TG/DTA) were used for the determination of thermal dehydration kinetics. According to the XRD results, mcallisterite, which has a powder diffraction file (pdf) number of "01-0701902," was formed under certain reaction parameters. Pure crystalline mcallisterite had diagnostic FT-IR and Raman vibration peaks and according to the SEM analysis, for the minerals which were synthesized at $60^{\circ} \mathrm{C}$ and 30 min of reaction time, particle size was between 398.30 and $700.06 \mathrm{~nm}$. Its $\mathrm{B}_{2} \mathrm{O}_{3}$ content and reaction yield were $50.80 \pm 1.12 \%$ and $85.80 \pm 0.61 \%$, respectively. Finally, average activation energies (conversion values $(\alpha)$ that were selected between 0.1 and 0.6 ) were calculated as $100.40 \mathrm{~kJ} / \mathrm{mol}$ and $98.31 \mathrm{~kJ} / \mathrm{mol}$ according to Ozawa and Kissinger-Akahira-Sunose (KAS) methods, respectively.
\end{abstract}

\section{Introduction}

Boron most often occurs in nature as borates which can be classified by the kind of metal it is complexed with. Magnesium borate minerals, which are a subclass of boron minerals, are inorganic compounds containing magnesium and boron. They are excellent additives for industry due to their high elasticity coefficient, heat resistance, and corrosion resistance [1]. Magnesium borates have specific applications in modified glass compositions, reinforcements in electronic ceramics, wide band gap semiconductors, aluminum/magnesium matrix alloys, antiwear additives such as thermoluminescence dosimeters, catalysts for the conversion of hydrocarbons, cathode ray tube screens, and X-ray screens [2-5].

Many kinds of magnesium borates having $x \mathrm{MgO} \cdot y \mathrm{~B}_{2} \mathrm{O}_{3}$. $z \mathrm{H}_{2} \mathrm{O}$ compositions can be found naturally in mixture with other metal borates or can be obtained in the laboratory by synthetic methods. Some examples of this type of borate hydrate minerals that have been synthesized are
$2 \mathrm{MgO} \cdot 3 \mathrm{~B}_{2} \mathrm{O}_{3} \cdot 17 \mathrm{H}_{2} \mathrm{O}, \quad \mathrm{MgO} \cdot 3 \mathrm{~B}_{2} \mathrm{O}_{3} \cdot 3.5 \mathrm{H}_{2} \mathrm{O}, 2 \mathrm{MgO} \cdot \mathrm{B}_{2} \mathrm{O}_{3}$. $\mathrm{H}_{2} \mathrm{O}, 2 \mathrm{MgO} \cdot 6 \mathrm{~B}_{2} \mathrm{O}_{3} \cdot 15 \mathrm{H}_{2} \mathrm{O}$, and $\mathrm{MgO} \cdot 3 \mathrm{~B}_{2} \mathrm{O}_{3} \cdot 7 \mathrm{H}_{2} \mathrm{O}$ [6-13]. Mcallisterite is a type of magnesium borate with the chemical formula $\mathrm{Mg}_{2}\left[\mathrm{~B}_{6} \mathrm{O}_{7}(\mathrm{OH})_{6}\right]_{2} \cdot 9 \mathrm{H}_{2} \mathrm{O}$. It has the appearance of very fine aggregates and white-colorless crystals, hardness of 2.5 Mohs, and low water solubility. Mcallisterite reserves are found in Argentina, China, Kazakhstan, and USA; however, in these reserves, magnesium and calcium borates are found in a mixture and purification is needed [14]. General hydrothermal synthesis procedures for magnesium borates involve the reactions of suitable raw materials at high temperatures such as $>100^{\circ} \mathrm{C}$ or by double salt phase transformation. The type of experimental procedure used has effects on the product's crystal properties and size.

In literature, there are some examples of materials' surface modification by changing the reaction temperatures and reaction times. According to these studies, nanoscale materials can be synthesized as different crystal types [6-13, 15].

Hydrothermal processes have several advantages over the other types of conventional synthesis processes such as 


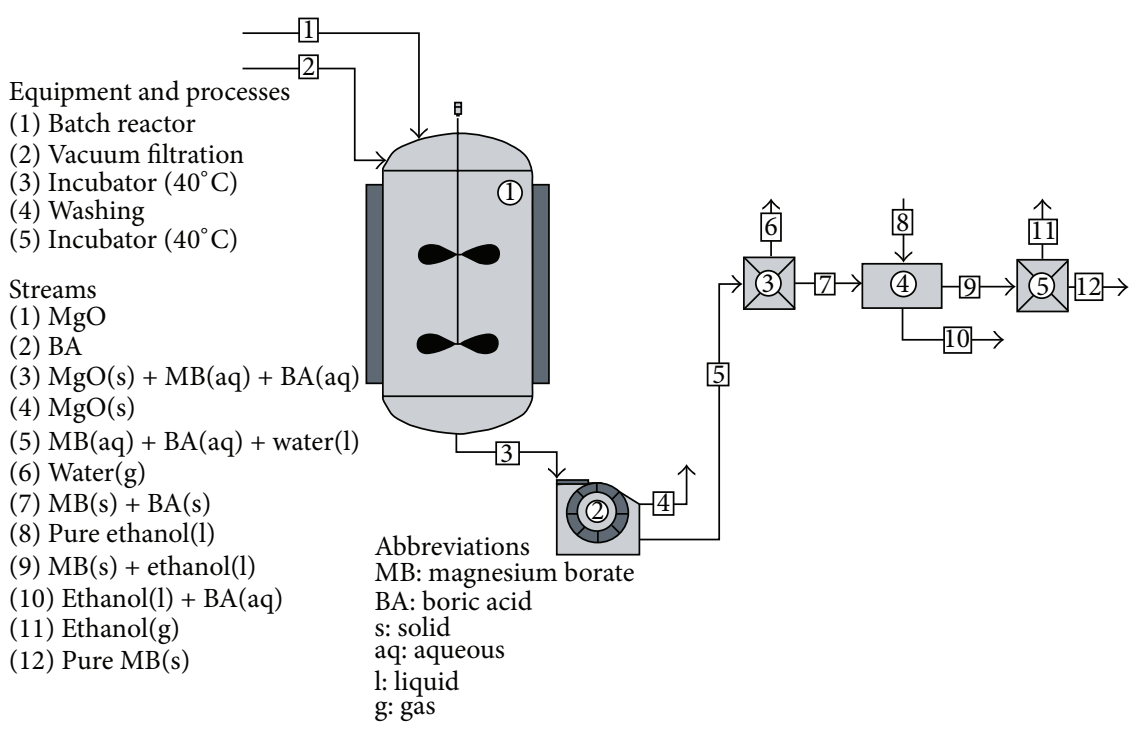

FIGURE 1: Synthesis procedure of magnesium borates.

solid-state method in regard to energy conservation, better nucleation control, and lower temperature and pressure of operation $[16,17]$. Higher reaction temperatures and longer reaction times cause increases in process cost.

Dehydrations of crystalline solids represent an important group of heterogeneous reactions. Characteristic dehydration features of materials should be known in order to determine design parameters of equipment and to decrease mass of required materials, thus reducing the transportation costs. The decomposition process of the hydrated boron mineral, which usually involves dehydration and dehydroxylation, can be explained by the removal of crystal water from structure [5-19]. Dehydration behaviors of different types of metal borate minerals have been determined by thermogravimetric analyses such as TG/DTA [1].

The effects of different nonisothermal kinetic methods on the thermal dehydration of inderite were examined by $\mathrm{Zhu}$ et al. [7]. Changes in ulexite structure resulting from heating and the reaction kinetic parameters were studied by Ener et al. [20] and Tunç et al. [21]; their results showed that ulexite could be turned to amorphous phase of $\mathrm{NaB}_{3} \mathrm{O}_{5}$ at $855^{\circ} \mathrm{C}$. Waclawska [22] studied the effect of mechanical treatment on phase transitions of calcium borate and colemanite and internal structure reconstitution processes of ground colemanite. There have also been some studies regarding dehydration kinetics of synthesized boron compounds. Kanturk et al. [23] studied dehydration kinetic parameters such as activation energy and preexponential factors of synthesized sodium metaborate tetrahydrate $\left(\mathrm{NaB}(\mathrm{OH})_{4} \cdot 2 \mathrm{H}_{2} \mathrm{O}\right)$. Kinetic analyses of boric acid thermal decomposition were studied by thermogravimetric analysis and different kinds of nonisothermal kinetic methods were used for the calculation of parameters [24]. Guo et al. [25] have investigated the decomposition and oxidation behavior of $\mathrm{MgB}_{2}$ using TG, XRD, and SEM-EDS.

In literature, despite the extensively reported synthesis of magnesium borates, only inderite minerals' kinetic behavior has been studied. To date, there have been no studies regarding the kinetic behavior of mcallisterite.
In this study, the low temperature $\left(0-70^{\circ} \mathrm{C}\right)$ synthesis of a specific kind of magnesium borate mineral, namely, mcallisterite, is aimed. Therefore, in literature, Derun et al. [1] studied the magnesium borates between 80 and $100^{\circ} \mathrm{C}$ and synthesized a specific kind of magnesium borate mineral, namely, admontite. The other aim of this study is to determine the kinetic parameters (activation energy and coefficient factor) of mcallisterite mineral which was not studied before, with both Ozawa [26] and KAS [27, 28] nonisothermal kinetic methods.

\section{Materials and Methods}

2.1. Synthesis of Mcallisterite. The raw materials used in synthesis were boric acid $\left(\mathrm{H}_{3} \mathrm{BO}_{3}\right)$, which was provided from Kirka Boron Management Plant (ETi Mine Kirka Works) in Eskisehir, Turkey, and magnesium oxide ( $\mathrm{MgO})$, which was provided from Merck Chemicals. $\mathrm{H}_{3} \mathrm{BO}_{3}$ was crushed, grinded, and sieved and $\mathrm{MgO}$ was used as supplied.

The synthesis procedure of magnesium borates is given in Figure 1. Experiments were carried out at the reaction temperatures between 0 and $70^{\circ} \mathrm{C}$ and reaction time between 30 and 240 minutes. Each product was coded by initial letters of the raw materials ( $\mathrm{M}: \mathrm{MgO}$ and $\mathrm{H}: \mathrm{H}_{3} \mathrm{BO}_{3}$ ), reaction temperature, and reaction time. For instance, "MH-60-30" indicated the product synthesized at a reaction temperature of $60^{\circ} \mathrm{C}$ and at a reaction time of $30 \mathrm{~min}$.

2.2. Instrumental Analyses. Philips PANalytical XRD was used for identification of reaction products. X-rays were produced from a $\mathrm{Cu}-\mathrm{K} \alpha$ tube at $45 \mathrm{kV}$ and $40 \mathrm{~mA}$. The parameters used in the analyses were $0.030^{\circ}$ step, $0.50 \mathrm{~s}$ time for step, $0.060^{\circ} \mathrm{C} / \mathrm{s}$ scan speed, and $0-60^{\circ}$ range. ICSD patterns were scanned using the inorganic library built into the instrument's program. Synthesized minerals were then subjected to FT-IR analyses using a Perkin Elmer FT-IR with universal attenuation total reflectance (ATR) sampling 
accessory with a diamond/ZnSe crystal. The measurement range was $1800-650 \mathrm{~cm}^{-1}$, scan number was 4 , and resolution was $4 \mathrm{~cm}^{-1}$. For further analysis, Perkin Elmer Brand Raman Station $400 \mathrm{~F}$ was used for Raman spectroscopy. In these analyses, the exposure time was 4 seconds and the number of exposures was 4 . Measurement range was $1800-250 \mathrm{~cm}^{-1}$ and the data interval was $2 \mathrm{~cm}^{-1}$. During the experiments, $100 \%$ laser power was used. Surface morphologies of synthesized minerals were obtained using a CamScan Apollo 300 field-emission SEM (20 kV and magnification 20000).

2.3. $\mathrm{B}_{2} \mathrm{O}_{3}$ Analyses and Reaction Yields. Both $\mathrm{B}_{2} \mathrm{O}_{3}$ analyses and calculations of reaction yields were performed according to Derun et al. [1].

2.4. Thermal Dehydration Kinetics. Thermal dehydration behavior of highly crystalline pure mcallisterite was studied between the temperature ranges of 20 and $720^{\circ} \mathrm{C}$ with a Perkin Elmer Diamond TG/DTA. Purely obtained mcallisterite mineral was subjected to five different heating rates $\left(2^{\circ} \mathrm{C} / \mathrm{min}, 5^{\circ} \mathrm{C} / \mathrm{min}, 10^{\circ} \mathrm{C} / \mathrm{min}, 15^{\circ} \mathrm{C} / \mathrm{min}\right.$, and $\left.20^{\circ} \mathrm{C} / \mathrm{min}\right)$ in an inert (nitrogen) atmosphere. Kinetic parameters such as activation energy $\left(E_{a}\right)$ and coefficient constants $\left(k_{0}\right)$ were calculated by Ozawa and KAS nonisothermal kinetic methods.

In the Ozawa kinetic method (1), values of $1 / T$ are plotted against $\log \beta$ for each conversion value $(\alpha)$, where $T$ is the thermodynamic temperature and $\beta$ is heating rate. Activation energy $\left(E_{a}\right)$ is calculated from the slope of parallel lines. $R$ is the gas constant. Consider

$$
\log \beta=\log \left(\frac{k_{0} E_{a}}{R}\right)-2.315-0.4567\left(\frac{E_{a}}{R T}\right)-\log (g(\alpha)) .
$$

In the KAS kinetic method (2), the kinetic parameters are determined from the plot of $1 / T$ against the left side of equation for each $\alpha$ value:

$$
\ln \left(\frac{\beta}{T^{2}}\right)=\ln \left(\frac{k_{0} E_{a}}{R \cdot g(x)}\right)-\frac{E_{a}}{R T}
$$

2.5. Thermal Conversion of Mcallisterite. In order to investigate and characterize the product obtained after the thermal dehydration kinetics study, mcallisterite mineral was placed in a Protherm MOS 180/4 high temperature furnace with $10^{\circ} \mathrm{C} / \mathrm{min}$ temperature increment to a maximum temperature of $720^{\circ} \mathrm{C}$ in nitrogen flowing $(5 \mathrm{~mL} / \mathrm{min})$ atmosphere. After the thermal conversion, the product was analyzed by XRD with the same parameters given in Section 2.2.

\section{Results and Discussion}

3.1. XRD Results. The magnesium and boron sources used in the experiments were found to be periclase $[\mathrm{MgO}]$ and sassolite $\left[\mathrm{H}_{3} \mathrm{BO}_{3}\right]$ with powder diffraction file (pdf) numbers of 01-087-0651 and 01-073-2158, respectively.

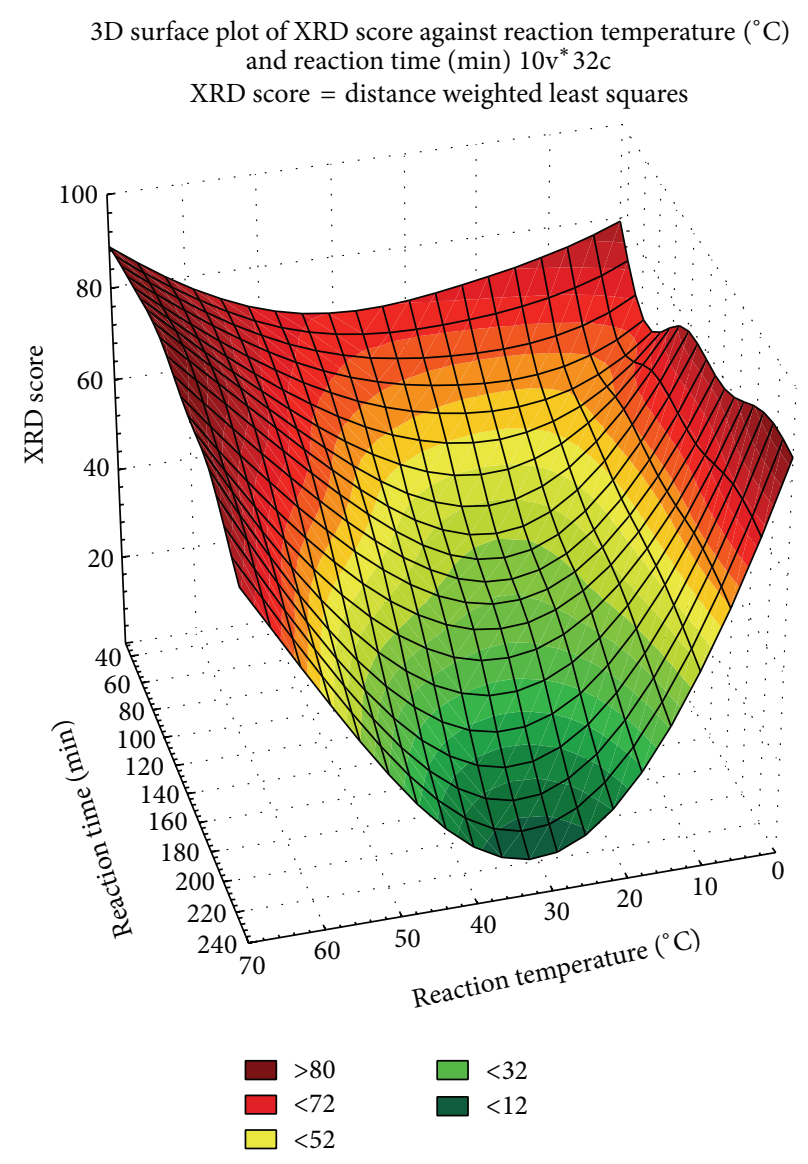

FIGURE 2: Modeling graph of mcallisterite crystal scores, which is drawn using Statsoft Statistica.

Products of the synthesis were determined to be mcallisterite $\left[\mathrm{Mg}_{2}\left(\mathrm{~B}_{6} \mathrm{O}_{7}(\mathrm{OH})_{6}\right)_{2} \cdot 9 \mathrm{H}_{2} \mathrm{O}\right]$ (pdf 01-070-1902), admontite $\left[\mathrm{MgO}\left(\mathrm{B}_{2} \mathrm{O}_{3}\right)_{3} \cdot 7 \mathrm{H}_{2} \mathrm{O}\right]$ (pdf 01-076-0540), and magnesium borate hydrate $\left[\mathrm{MgB}_{6} \mathrm{O}_{7}(\mathrm{OH})_{6} \cdot 3\left(\mathrm{H}_{2} \mathrm{O}\right)\right]$ (pdf 01-073-0638).

XRD scores of synthesized minerals, where a perfect crystal structure is equal to 100 , are given in Table 1 . MH-060, MH-10-30, MH-60-30, and MH-70-60 were pure mcallisterite. $\mathrm{MH}-20-120, \mathrm{MH}-20-240, \mathrm{MH}-30-240$, and $\mathrm{MH}-40-$ 240 were pure admontite. $\mathrm{MH}-70-240$ was a mixture of three types of magnesium borate hydrate minerals.

Mcallisterite formation as a function of reaction temperature and reaction time is presented in Figure 2. Mcallisterite crystal formation decreased from $0^{\circ} \mathrm{C}$ to $30^{\circ} \mathrm{C}$ and increased from $30^{\circ} \mathrm{C}$ to $70^{\circ} \mathrm{C}$. Also, mcallisterite formation had a general tendency to increase with decreasing reaction times except at the temperatures of $0^{\circ} \mathrm{C}, 30^{\circ} \mathrm{C}, 50^{\circ} \mathrm{C}$, and $60^{\circ} \mathrm{C}$. At $0^{\circ} \mathrm{C}$ and $50^{\circ} \mathrm{C}$, the maximum formation was seen at $120 \mathrm{~min}$, whereas at $30^{\circ} \mathrm{C}$ and $60^{\circ} \mathrm{C}$, the maximum formation was seen at $60 \mathrm{~min}$.

The highest mcallisterite crystal scores were seen in $\mathrm{MH}$ 60-30 and MH-70-60 with values of 84 and 85, respectively. Since the XRD crystal scores for MH-60-30 and MH-70-60 were approximately the same, according to green chemistry concepts, $\mathrm{MH}-60-30$ was selected as the best reaction parameter and subjected to TG/DTA kinetic analyses. 
TABLE 1: XRD results of the synthesized magnesium borate minerals.

\begin{tabular}{|c|c|c|c|c|}
\hline \multirow{2}{*}{ Reaction temperature $\left({ }^{\circ} \mathrm{C}\right)$} & \multirow{2}{*}{ Reaction time (min) } & \multicolumn{3}{|c|}{ XRD scores of } \\
\hline & & 01-070-1902 & 01-076-0540 & $01-073-0638$ \\
\hline \multirow{4}{*}{0} & 30 & 78 & 30 & - \\
\hline & 60 & 80 & - & - \\
\hline & 120 & 84 & 25 & - \\
\hline & 240 & 76 & 45 & - \\
\hline \multirow{4}{*}{10} & 30 & 72 & - & - \\
\hline & 60 & 8 & 6 & - \\
\hline & 120 & 69 & 61 & - \\
\hline & 240 & 76 & 45 & - \\
\hline \multirow{4}{*}{20} & 30 & 85 & 31 & - \\
\hline & 60 & 77 & 51 & - \\
\hline & 120 & - & 71 & - \\
\hline & 240 & - & 73 & - \\
\hline \multirow{4}{*}{30} & 30 & 77 & 70 & - \\
\hline & 60 & 84 & 71 & - \\
\hline & 120 & 50 & 79 & - \\
\hline & 240 & - & 81 & - \\
\hline \multirow{4}{*}{40} & 30 & 52 & 81 & - \\
\hline & 60 & 29 & 80 & - \\
\hline & 120 & 39 & 80 & - \\
\hline & 240 & - & 81 & - \\
\hline \multirow{4}{*}{50} & 30 & 66 & 78 & - \\
\hline & 60 & 86 & 59 & - \\
\hline & 120 & 88 & 52 & - \\
\hline & 240 & 45 & 79 & - \\
\hline \multirow{4}{*}{60} & 30 & 84 & - & - \\
\hline & 60 & 89 & 16 & - \\
\hline & 120 & 85 & 63 & - \\
\hline & 240 & 82 & 82 & - \\
\hline \multirow{4}{*}{70} & 30 & 87 & 18 & - \\
\hline & 60 & 85 & - & - \\
\hline & 120 & 85 & 56 & - \\
\hline & 240 & 57 & 84 & 23 \\
\hline
\end{tabular}

pdf number $=01-070-1902$, mcallisterite, $\mathrm{Mg}_{2}\left(\mathrm{~B}_{6} \mathrm{O}_{7}(\mathrm{OH})_{6}\right)_{2} \cdot 9\left(\mathrm{H}_{2} \mathrm{O}\right)$.

pdf number $=01-076-0540$, admontite, $\mathrm{MgO}\left(\mathrm{B}_{2} \mathrm{O}_{3}\right)_{3} \cdot 7\left(\mathrm{H}_{2} \mathrm{O}\right)$.

pdf number $=01-073-0638, \mathrm{MgB}_{6} \mathrm{O}_{7}(\mathrm{OH})_{6} \cdot 3\left(\mathrm{H}_{2} \mathrm{O}\right)$.

XRD patterns of synthesized pure mcallisterite minerals are given in Figure 3. As seen in Figure 3, all the characteristic peaks of mcallisterite were seen and higher count values were observed for MH-60-30 and MH-70-60 which is consistent with their higher crystal scores.

3.2. FT-IR and Raman Spectrum Results. FT-IR spectrum of product is given in Figure 4. The first peak at about 1650$1660 \mathrm{~cm}^{-1}$ is the bending of $\mathrm{H}-\mathrm{O}-\mathrm{H}[\delta(\mathrm{H}-\mathrm{O}-\mathrm{H})]$. The peaks at $1412-1337 \mathrm{~cm}^{-1}$ can be explained by asymmetric stretching of 3-coordinate boron $\left[v_{\mathrm{as}}\left(\mathrm{B}_{(3)}-\mathrm{O}\right)\right]$. The peak around $1238 \mathrm{~cm}^{-1}$ represents the bending of $\mathrm{B}-\mathrm{O}-\mathrm{H}[\delta(\mathrm{B}-\mathrm{O}-\mathrm{H})]$. Asymmetric and symmetric stretching of 4-coordinate boron $\left[v_{\text {as }}\left(\mathrm{B}_{(4)}-\mathrm{O}\right)\right],\left[v_{\mathrm{s}}\left(\mathrm{B}_{(4)}-\mathrm{O}\right)\right]$ were seen between the peaks of $1080-961 \mathrm{~cm}^{-1}$ and $857-812 \mathrm{~cm}^{-1}$, respectively. The last peak of $671 \mathrm{~cm}^{-1}$ was the bending of 3 -coordinate boron $\left[\delta\left(\mathrm{B}_{(3)}-\mathrm{O}\right)\right]$.

Raman spectrum of the pure mcallisterite minerals is given in Figure 5. From the Raman results, symmetric stretching of 3-coordinate boron $\left[v_{s}\left(\mathrm{~B}_{(3)}-\mathrm{O}\right)\right]$ was seen at the peaks between 951 and $879 \mathrm{~cm}^{-1} . \delta\left(\mathrm{B}_{(3)}-\mathrm{O}\right)$ was seen at the peaks between 680 and $678 \mathrm{~cm}^{-1}$. The characteristic peaks of magnesium borates, which are $v_{p}\left[\mathrm{~B}_{6} \mathrm{O}_{7}(\mathrm{OH})_{6}\right]^{2-}$ and $v_{p}\left[\mathrm{~B}_{3} \mathrm{O}_{3}(\mathrm{OH})_{4}\right]^{-}$, were seen at the peak values around $640 \mathrm{~cm}^{-1}$. At the peak of $528 \mathrm{~cm}^{-1}, \delta\left(\mathrm{B}_{(3)}-\mathrm{O}\right)$ and bending of 4 -coordinate boron $\left[\delta\left(\mathrm{B}_{(4)}-\mathrm{O}\right)\right]$ were seen. The last peaks which are lower than the $490 \mathrm{~cm}^{-1}$ can be explained by the $\delta\left(\mathrm{B}_{(4)}-\mathrm{O}\right)$. 


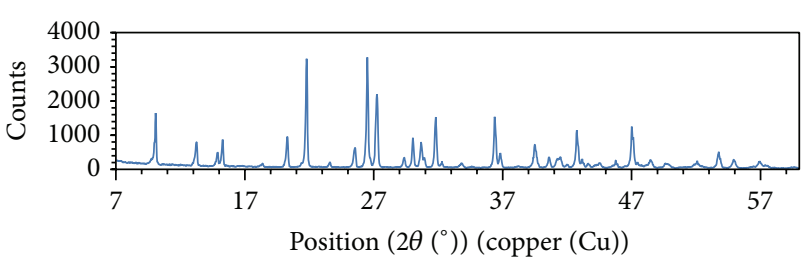

(a)

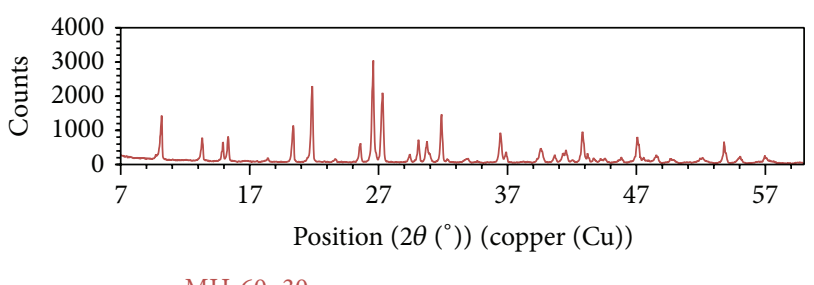

(b)

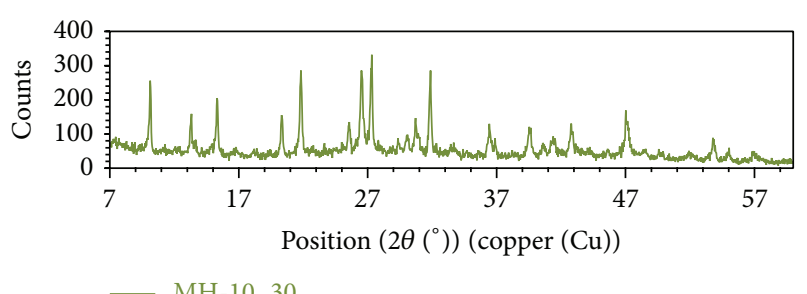

(c)

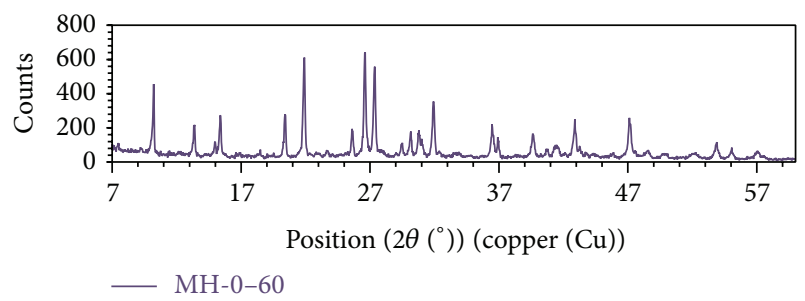

(d)

FIGURE 3: XRD patterns of synthesized pure mcallisterite minerals.

The FT-IR and Raman results are both consistent with the literature $[29,30]$.

3.3. SEM Results. SEM surface morphologies of the synthesized pure mcallisterite minerals are given in Figure 6. At $10^{\circ} \mathrm{C}$ and $0^{\circ} \mathrm{C}$, crystals were seen as rectangular shapes due to overlapping of layers and single crystals. Particle sizes of the crystals at $10^{\circ} \mathrm{C}$ and $0^{\circ} \mathrm{C}$ were between $348 \mathrm{~nm}-1.32 \mu \mathrm{m}$ and $285-544 \mathrm{~nm}$, respectively. Cylindrical crystal formations occurred at $60^{\circ} \mathrm{C}$ and $70^{\circ} \mathrm{C}$, where particle sizes were $344-$ $719 \mathrm{~nm}$ and $398-700 \mathrm{~nm}$, respectively.

3.4. $\mathrm{B}_{2} \mathrm{O}_{3}$ Results and Reaction Yields. $\mathrm{B}_{2} \mathrm{O}_{3}$ contents of the synthesized minerals are given in Table 2. Highest and lowest $\mathrm{B}_{2} \mathrm{O}_{3}$ were seen in $\mathrm{MH}-50-30(51.62 \pm 1.07 \%)$ and $\mathrm{MH}-0-30$ $(44.59 \pm 1.34 \%)$. Pure mcallisterite minerals $\mathrm{B}_{2} \mathrm{O}_{3}$ contents

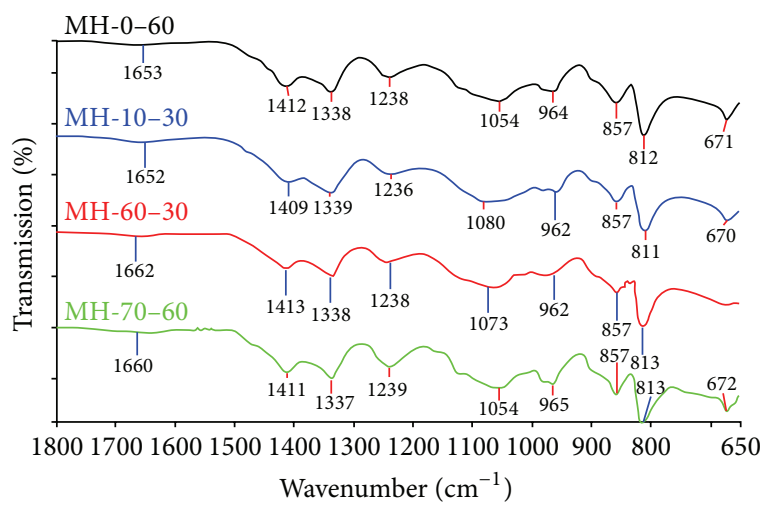

FIGURE 4: FT-IR spectrum of synthesized pure mcallisterite minerals.

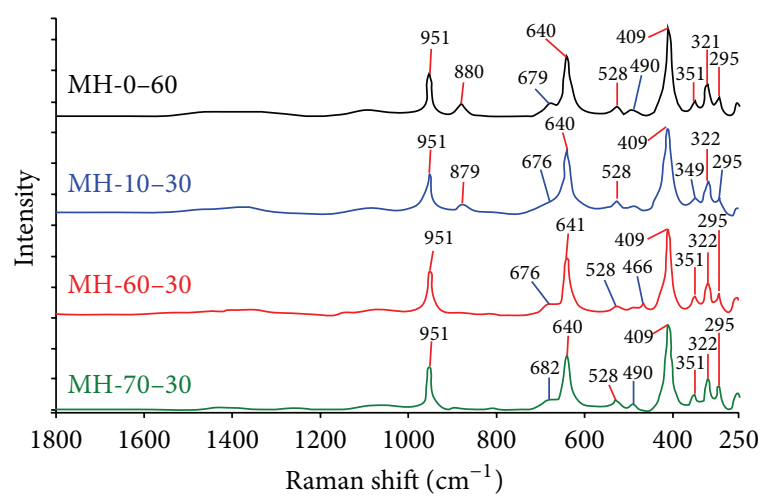

FIGURE 5: Raman spectrum of synthesized pure mcallisterite minerals.

were $53.25 \pm 1.20 \%$ in $\mathrm{MH}-70-60,54.17 \pm 0.87 \%$ in $\mathrm{MH}-60$ $30,49.91 \pm 1.28 \%$ in $\mathrm{MH}-10-30$, and $45.92 \pm 0.54 \%$ in $\mathrm{MH}-0$ 60 . These results were in mutual agreement with theoretical $\mathrm{B}_{2} \mathrm{O}_{3}$ content of mcallisterite mineral (54.35\%).

Average reaction yield of the $\mathrm{MH}-60-30$ was $85.80 \pm$ $0.61 \%$ as calculated from the four repeated syntheses.

3.5. Kinetic Analysis Results. TG and DTG analyses of MH60-30 are shown in Figures 7 and 8, respectively. The analyses showed that mcallisterite lost its crystal water via a two-step process at the heating rate of $2^{\circ} \mathrm{C} / \mathrm{min}$ and by a single-step process at heating rates of greater than $2^{\circ} \mathrm{C} / \mathrm{min}\left(5^{\circ} \mathrm{C} / \mathrm{min}\right.$, $10^{\circ} \mathrm{C} / \mathrm{min}, 15^{\circ} \mathrm{C} / \mathrm{min}$, and $20^{\circ} \mathrm{C} / \mathrm{min}$ ).

The first step at the heating rate of $2^{\circ} \mathrm{C} / \mathrm{min}$ was a rapid dehydration, where the initial, peak, and final temperatures were $90.81^{\circ} \mathrm{C}, 150.64^{\circ} \mathrm{C}$, and $155.94^{\circ} \mathrm{C}$, respectively. In the second step, initial, peak, and final temperatures were $155.94^{\circ} \mathrm{C}$, $165.79^{\circ} \mathrm{C}$, and $300.00^{\circ} \mathrm{C}$. Weight decreases were $16.416 \%$ and $19.359 \%$ for the first and second steps, respectively. Total weight loss was $35.775 \%$.

The initial, peak, and final temperatures and weight losses at other heating rates are given in Table 3 . The average weight loss, calculated using all of the heating rates, was $35.379 \%$, which is close to structural water content $(35.16 \%)$ of mcallisterite mineral. 


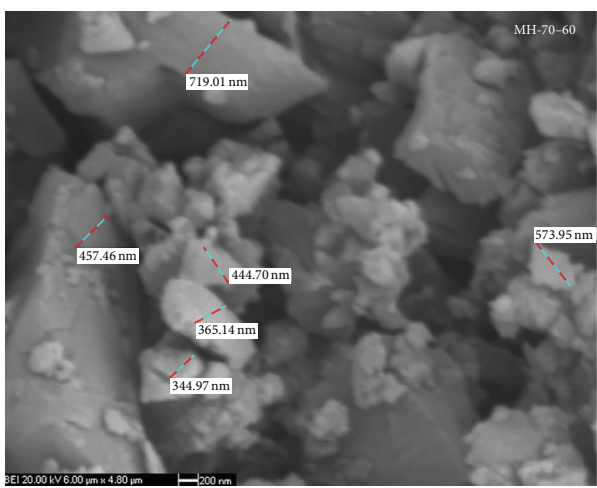

(a)

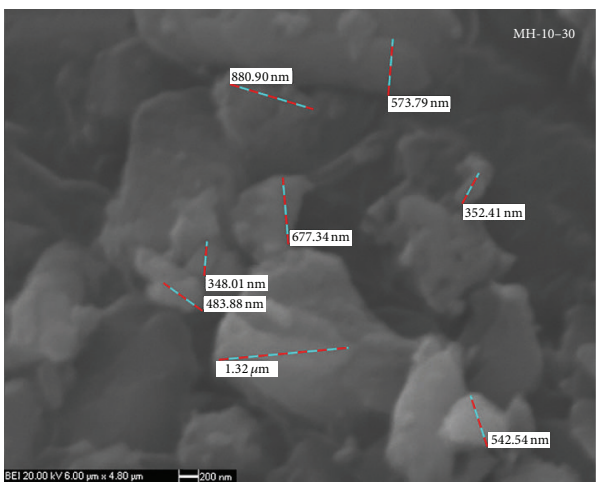

(c)

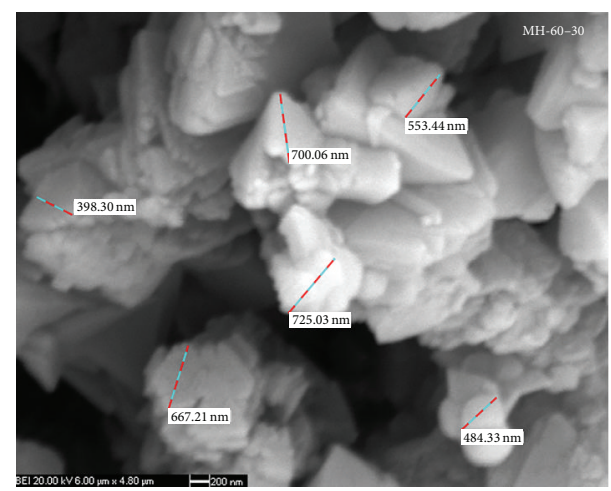

(b)

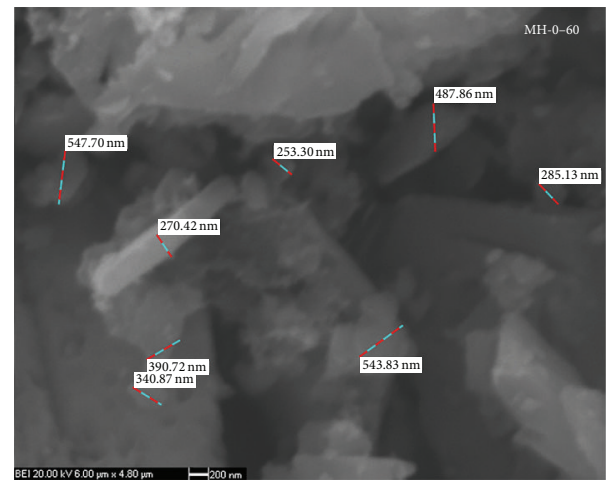

(d)

FIGURE 6: SEM surface morphologies of synthesized pure mcallisterite minerals at 20000x magnification.

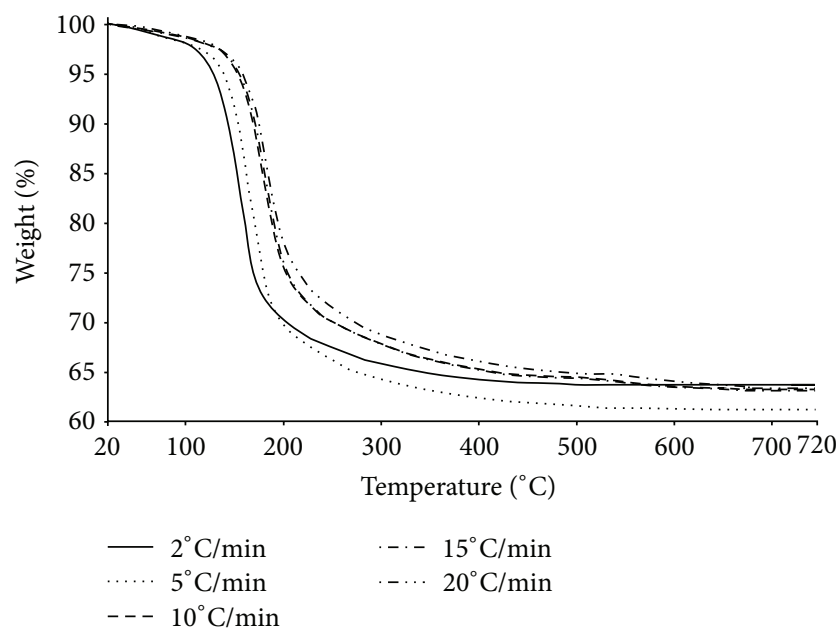

FIGURE 7: TG curve of synthesized pure mcallisterite.

Ozawa and KAS nonisothermal kinetic methods were applied for conversion values $(\alpha)$ between 0.1 and 0.9 . In the Ozawa kinetic method, $\log (\beta)$ values were plotted against $1 / T$ values for each $\alpha$ value (Figure 9 ). For each heating rate kinetic parameter of $E_{a}$ was calculated from the slope of the curves.

Likewise, in the KAS kinetic method, $\ln \left(\beta / T^{2}\right)$ was plotted against $1 / T$ for each $\alpha$ value (Figure 10). Kinetic

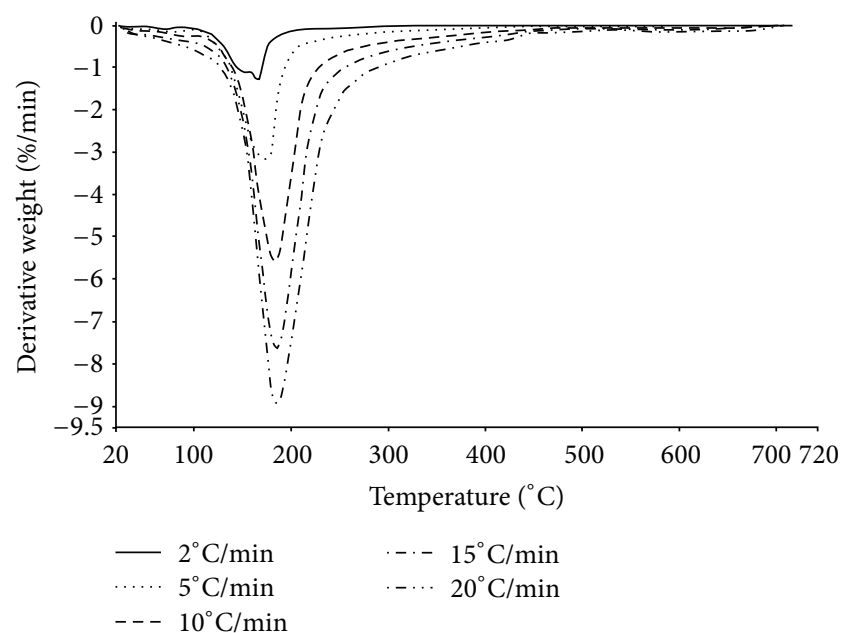

FIGURE 8: DTG curve of synthesized pure mcallisterite.

parameters of $E_{a}$ and $k_{0}$ for each heating rate were calculated from the intercept and slopes of the curves, respectively.

$E_{a}, k_{0}$, and the correlation coefficient $\left(R^{2}\right)$ values obtained for each curve are shown in Table 4.

The activation energy values were calculated as 47.81$101.18 \mathrm{~kJ} / \mathrm{mol}$ and $53.91-103.95 \mathrm{~kJ} / \mathrm{mol}$ according to Ozawa and KAS methods, respectively. $k_{0}$ values were between 0.0002 and 2913.89 according to KAS. 


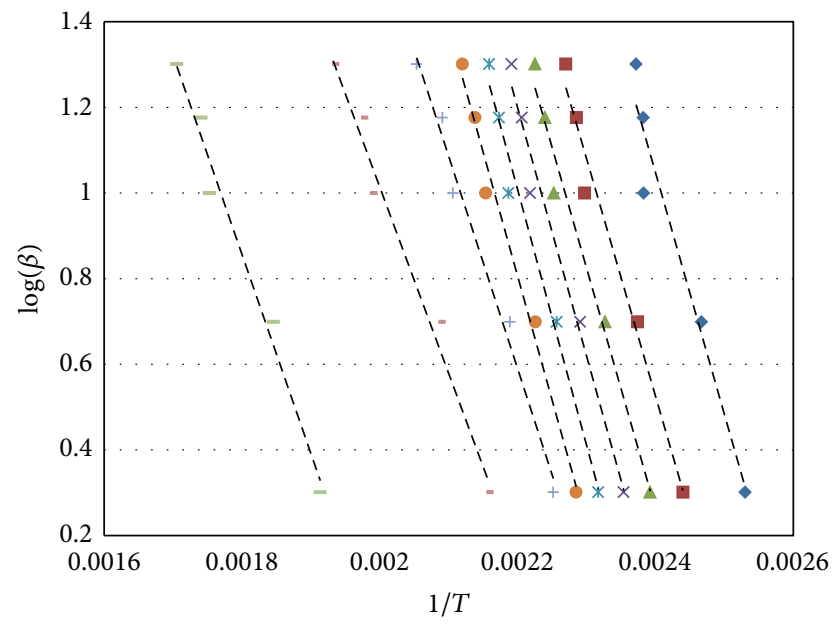

$$
\begin{array}{lll}
\text { - } a=0.1 & \times a=0.4 & +a=0.7 \\
\text { - } a=0.2 & \text { * } a=0.5 & -a=0.8 \\
\triangle a=0.3 & \text { - } a=0.6 & -a=0.9
\end{array}
$$

FIGURE 9: Ozawa analysis of mcallisterite.

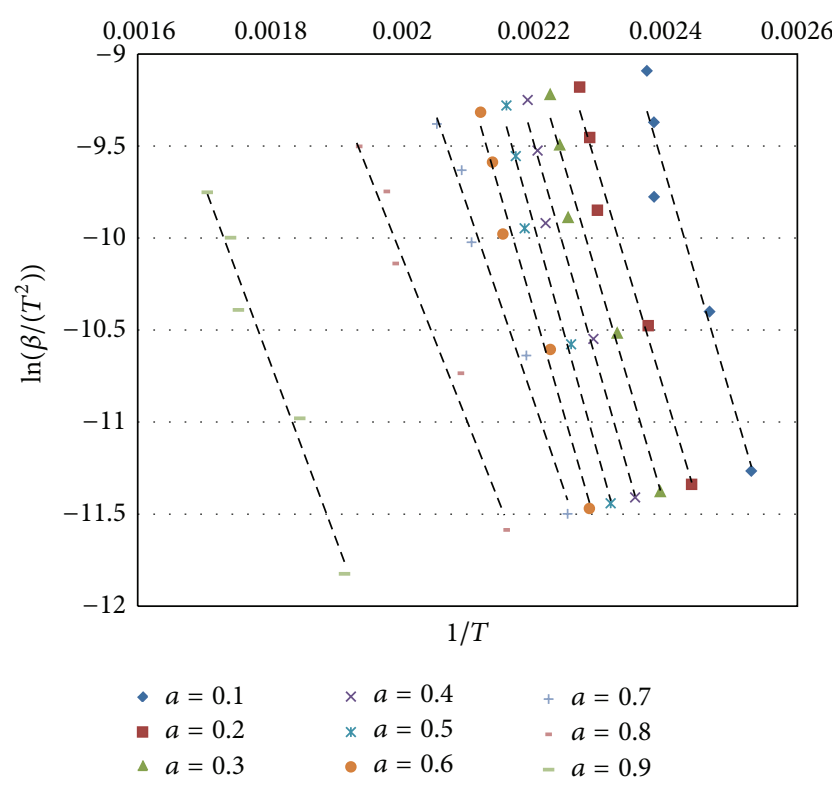

FIGURE 10: KAS analysis of mcallisterite.

Average activation energies of mcallisterite mineral calculated for the conversion values between 0.1 and 0.6 were $100.40 \mathrm{~kJ} / \mathrm{mol}$ and $98.31 \mathrm{~kJ} / \mathrm{mol}$ according to Ozawa and KAS, respectively.

3.6. Thermal Conversion Results of Mcallisterite. Thermal conversion results showed that mcallisterite mineral lost $35.74 \pm 0.32 \%$ of its weight. This was in agreement with the TG analyses and mcallisterite's theoretical structural water content of $35.16 \%$, which is equal to 15 molar equivalent of water.

Also, XRD analysis showed that the mcallisterite mineral had lost all of its structure water and changed to dehydrated

\begin{tabular}{|c|c|c|}
\hline $\begin{array}{l}\text { Reaction } \\
\text { temperature }\left({ }^{\circ} \mathrm{C}\right)\end{array}$ & $\begin{array}{l}\text { Reaction time } \\
(\min )\end{array}$ & $\mathrm{B}_{2} \mathrm{O}_{3}$ content $(\%)$ \\
\hline \multirow{4}{*}{0} & 30 & $44.58 \pm 1.34$ \\
\hline & 60 & $45.92 \pm 0.54$ \\
\hline & 120 & $47.06 \pm 0.54$ \\
\hline & 240 & $45.73 \pm 0.27$ \\
\hline \multirow{4}{*}{10} & 30 & $49.91 \pm 1.28$ \\
\hline & 60 & $47.06 \pm 0.54$ \\
\hline & 120 & $45.92 \pm 0.54$ \\
\hline & 240 & $47.63 \pm 0.81$ \\
\hline \multirow{4}{*}{20} & 30 & $47.82 \pm 1.07$ \\
\hline & 60 & $49.53 \pm 0.27$ \\
\hline & 120 & $49.72 \pm 0.54$ \\
\hline & 240 & $48.01 \pm 0.81$ \\
\hline \multirow{4}{*}{30} & 30 & $45.54 \pm 1.15$ \\
\hline & 60 & $47.54 \pm 0.13$ \\
\hline & 120 & $46.11 \pm 0.81$ \\
\hline & 240 & $48.20 \pm 1.68$ \\
\hline \multirow{4}{*}{40} & 30 & $48.96 \pm 1.07$ \\
\hline & 60 & $48.20 \pm 1.07$ \\
\hline & 120 & $47.06 \pm 0.54$ \\
\hline & 240 & $46.68 \pm 1.61$ \\
\hline \multirow{4}{*}{50} & 30 & $51.62 \pm 1.07$ \\
\hline & 60 & $48.96 \pm 1.07$ \\
\hline & 120 & $50.86 \pm 0.54$ \\
\hline & 240 & $51.43 \pm 0.81$ \\
\hline \multirow{4}{*}{60} & 30 & $54.17 \pm 0.87$ \\
\hline & 60 & $52.87 \pm 1.25$ \\
\hline & 120 & $53.18 \pm 0.94$ \\
\hline & 240 & $50.17 \pm 1.24$ \\
\hline \multirow{4}{*}{70} & 30 & $50.83 \pm 0.84$ \\
\hline & 60 & $53.25 \pm 1.20$ \\
\hline & 120 & $49.62 \pm 1.06$ \\
\hline & 240 & $53.84 \pm 1.34$ \\
\hline
\end{tabular}

TABLE 2: $\mathrm{B}_{2} \mathrm{O}_{3}$ contents (\%) of the synthesized magnesium borate minerals.

magnesium minerals $\mathrm{Mg}\left(\mathrm{B}_{2} \mathrm{O}_{3}\right)_{2}$ (pdf 01-076-0666) and $\mathrm{B}_{2} \mathrm{O}_{3}$ (pdf 01-072-0626). The obtained $\mathrm{Mg}\left(\mathrm{B}_{2} \mathrm{O}_{3}\right)_{2}$ and $\mathrm{B}_{2} \mathrm{O}_{3}$ crystal scores were 71 and 24, respectively. At this step, in order to obtain pure $\mathrm{Mg}\left(\mathrm{B}_{2} \mathrm{O}_{3}\right)_{2}$, the mixture was washed with pure ethanol and then filtered and dried at $40^{\circ} \mathrm{C}$. Dried mineral was again subjected to XRD analyses and found as the same dehydrated magnesium mineral $\mathrm{Mg}\left(\mathrm{B}_{2} \mathrm{O}_{3}\right)_{2}$ with a crystal score of 83 . The increase in the crystal score means that the excess $\mathrm{B}_{2} \mathrm{O}_{3}$ content was removed and pure $\mathrm{Mg}\left(\mathrm{B}_{2} \mathrm{O}_{3}\right)_{2}$ was obtained. Also, according to the weight changes, before and after the washing step, $\mathrm{Mg}\left(\mathrm{B}_{2} \mathrm{O}_{3}\right)_{2}$ and $\mathrm{B}_{2} \mathrm{O}_{3}$ were found to be equimolar.

The crystallographic data obtained from XRD are shown in Table 5 for mcallisterite and $\mathrm{Mg}\left(\mathrm{B}_{2} \mathrm{O}_{3}\right)_{2}$. The $\mathrm{Mg}\left(\mathrm{B}_{2} \mathrm{O}_{3}\right)_{2}$ 
TABLE 3: Dehydration temperatures and weight losses of pure mcallisterite (MH-60-30).

\begin{tabular}{|c|c|c|c|c|c|c|}
\hline Heating rate $\left({ }^{\circ} \mathrm{C} / \mathrm{min}\right)$ & & & 5 & 10 & 15 & 20 \\
\hline Step & 1st & 2nd & $1 \mathrm{st}$ & 1st & $1 \mathrm{st}$ & 1 st \\
\hline$T_{i}\left({ }^{\circ} \mathrm{C}\right)$ & 90.81 & 155.94 & 100.00 & 106.51 & 111.88 & 119.74 \\
\hline$T_{p}\left({ }^{\circ} \mathrm{C}\right)$ & 150.64 & 165.79 & 172.14 & 182.94 & 184.86 & 186.22 \\
\hline$T_{f}\left({ }^{\circ} \mathrm{C}\right)$ & 155.94 & 300.00 & 347.79 & 394.36 & 396.80 & 497.95 \\
\hline$\Delta m(\%)$ & 16.416 & 19.359 & 35.109 & 35.537 & 35.517 & 34.958 \\
\hline$\Sigma \Delta m(\%)$ & & & 35.109 & 35.537 & 35.517 & 34.958 \\
\hline Average $\Delta m(\%)$ & \multicolumn{6}{|c|}{35.379} \\
\hline
\end{tabular}

$i$ initial; $p$ : peak; $f$ : final; $m$ : weight.

TABLE 4: Calculated kinetic parameters for KAS and Ozawa method.

\begin{tabular}{|c|c|c|c|c|c|}
\hline \multirow{3}{*}{$\alpha$} & \multicolumn{5}{|c|}{ Method } \\
\hline & \multicolumn{2}{|c|}{ Ozawa } & \multicolumn{3}{|c|}{ KAS } \\
\hline & $E_{a}(\mathrm{~kJ} / \mathrm{mol})$ & $R^{2}$ & $E_{a}(\mathrm{~kJ} / \mathrm{mol})$ & $k_{0}$ & $R^{2}$ \\
\hline 0.1 & 97.49 & 0.9909 & 95.58 & 2913.89 & 0.9896 \\
\hline 0.2 & 98.42 & 0.9888 & 96.38 & 1695.83 & 0.9872 \\
\hline 0.3 & 100.02 & 0.9871 & 97.95 & 1592.02 & 0.9852 \\
\hline 0.4 & 102.24 & 0.9869 & 100.18 & 1899.34 & 0.9849 \\
\hline 0.5 & 103.95 & 0.9889 & 101.87 & 1965.44 & 0.9872 \\
\hline 0.6 & 100.26 & 0.9914 & 97.88 & 470.80 & 0.9900 \\
\hline 0.7 & 83.07 & 0.9794 & 79.64 & 3.0520 & 0.9750 \\
\hline 0.8 & 64.07 & 0.9736 & 59.32 & 0.0106 & 0.9656 \\
\hline 0.9 & 53.91 & 0.9674 & 47.81 & 0.0002 & 0.9533 \\
\hline$\alpha$ & \multicolumn{2}{|c|}{ Average $E_{a}(\mathrm{~kJ} / \mathrm{mol})$} & \multicolumn{3}{|c|}{ Average $E_{a}(\mathrm{~kJ} / \mathrm{mol})$} \\
\hline $0.1-0.6$ & \multicolumn{2}{|c|}{100.40} & \multicolumn{3}{|c|}{98.31} \\
\hline
\end{tabular}

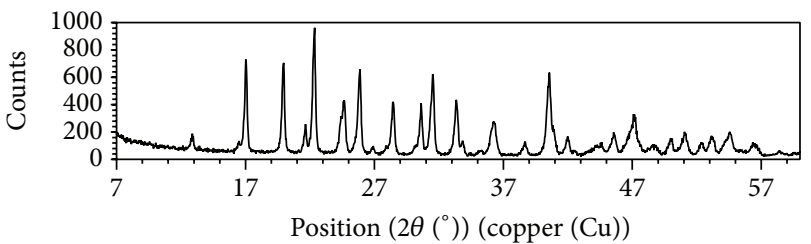

Figure 11: XRD pattern of $\mathrm{Mg}\left(\mathrm{B}_{2} \mathrm{O}_{3}\right)_{2}$.

XRD pattern is given in Figure 11, where in Figure 11 all the characteristic peaks of $\mathrm{Mg}\left(\mathrm{B}_{2} \mathrm{O}_{3}\right)_{2}$ were matched.

\section{Conclusions}

From the results of this study, it is seen that the pure mcallisterite minerals can be synthesized at a reaction temperature of $60^{\circ} \mathrm{C}$ with a $30 \mathrm{~min}$ reaction time by a hydrothermal method from the raw materials of $\mathrm{MgO}$ and $\mathrm{H}_{3} \mathrm{BO}_{3}$.

According to the XRD results, "01-070-1902" coded mcallisterite mineral $\left[\mathrm{Mg}_{2}\left(\mathrm{~B}_{6} \mathrm{O}_{7}(\mathrm{OH})_{6}\right) \cdot 9 \mathrm{H}_{2} \mathrm{O}\right]$ was synthesized. FT-IR and Raman spectrum had the characteristic bands of magnesium borates $[29,30]$. Surface morphologies revealed that proper crystals in nanoscale were obtained with particle size ranges of $398.30-700.06 \mathrm{~nm}$. The $\mathrm{B}_{2} \mathrm{O}_{3}$ content of the
MH-60-30 was $54.17 \pm 0.87 \%$, which is very close to the theoretical value of mcallisterite $(54.35 \%)$. The average reaction yield of $\mathrm{MH}-60-30$ was $85.80 \pm 0.61 \%$.

In thermal analysis at $2^{\circ} \mathrm{C} / \mathrm{min}$, mcallisterite lost its structure water content in a two-step process with the reaction scheme shown in (3) and (4):

$$
\begin{aligned}
& \text { 1st step: } \\
& \begin{array}{l}
\mathrm{Mg}_{2}\left(\mathrm{~B}_{6} \mathrm{O}_{7}(\mathrm{OH})_{6}\right)_{2} \cdot 9 \mathrm{H}_{2} \mathrm{O} \\
\quad \longrightarrow \mathrm{Mg}_{2}\left(\mathrm{~B}_{6} \mathrm{O}_{7}(\mathrm{OH})_{6}\right)_{2} \cdot 2 \mathrm{H}_{2} \mathrm{O}+\sim 7 \mathrm{H}_{2} \mathrm{O}
\end{array}
\end{aligned}
$$

2nd step:

$$
\begin{aligned}
\mathrm{Mg}_{2} & \left(\mathrm{~B}_{6} \mathrm{O}_{7}(\mathrm{OH})_{6}\right)_{2} \cdot 2 \mathrm{H}_{2} \mathrm{O} \\
& \longrightarrow 2\left(\mathrm{MgO}\left(\mathrm{B}_{2} \mathrm{O}_{3}\right)_{2}\right)+2 \mathrm{~B}_{2} \mathrm{O}_{3}+\sim 8 \mathrm{H}_{2} \mathrm{O}
\end{aligned}
$$

In the first step, mcallisterite lost approximately 7 moles of its structure water and in the second step the remaining 8 moles of structural water were lost. According to the thermal conversion results, the final components were equimolar $\mathrm{Mg}\left(\mathrm{B}_{2} \mathrm{O}_{3}\right)_{2}$ and $\mathrm{B}_{2} \mathrm{O}_{3}$.

In the thermal analyses at heating rates greater than $2^{\circ} \mathrm{C} / \mathrm{min}$, mcallisterite lost all 15 moles of structure water 
TABLE 5: Crystallographic data of synthesized mcallisterite and $\mathrm{MgO}\left(\mathrm{B}_{2} \mathrm{O}_{3}\right)_{2}$.

\begin{tabular}{|c|c|c|}
\hline Mineral name & Mcallisterite & Magnesium borate \\
\hline pdf number & 01-070-1902 & 01-076-0666 \\
\hline Chemical formula & $\mathrm{Mg}_{2}\left(\mathrm{~B}_{6} \mathrm{O}_{7}(\mathrm{OH})_{6}\right)_{2} \cdot 9\left(\mathrm{H}_{2} \mathrm{O}\right)$ & $\mathrm{MgO}\left(\mathrm{B}_{2} \mathrm{O}_{3}\right)_{2}$ \\
\hline Molecular weight (g/mole) & 768.56 & 179.55 \\
\hline Crystal system & Rhombohedral & Orthorhombic \\
\hline Space group & $\operatorname{Pr} 3 c$ (No. 167) & Pbca (No. 61) \\
\hline$a(\AA)$ & 11.5490 & 13.7300 \\
\hline$b(\AA)$ & 11.5490 & 7.9700 \\
\hline$c(\AA)$ & 35.5670 & 8.6200 \\
\hline$\alpha\left({ }^{\circ}\right)$ & 90.00 & 90.00 \\
\hline$\beta\left(^{\circ}\right)$ & 90.00 & 90.00 \\
\hline$\gamma\left({ }^{\circ}\right)$ & 120.00 & 90.00 \\
\hline$z$ & 6.00 & 8.00 \\
\hline Density (calculated) $\left(\mathrm{g} \cdot \mathrm{cm}^{-3}\right)$ & 1.86 & 2.53 \\
\hline \multirow{3}{*}{ Characteristic peaks $I(\%) / 2 \theta\left(^{\circ}\right)$} & $100.0 / 10.139$ & $100.0 / 22.291$ \\
\hline & $35.7 / 15.332$ & $94.4 / 17.033$ \\
\hline & $32.9 / 31.875$ & $80.9 / 19.921$ \\
\hline
\end{tabular}

content in a single step, turning into $\mathrm{Mg}\left(\mathrm{B}_{2} \mathrm{O}_{3}\right)_{2}$ and $\mathrm{B}_{2} \mathrm{O}_{3}$ by the reaction scheme shown in (5):

$$
\begin{aligned}
& \text { 1st step: } \\
& \begin{array}{l}
\mathrm{Mg}_{2}\left(\mathrm{~B}_{6} \mathrm{O}_{7}(\mathrm{OH})_{6}\right)_{2} \cdot 9 \mathrm{H}_{2} \mathrm{O} \\
\quad \longrightarrow 2\left(\mathrm{MgO}\left(\mathrm{B}_{2} \mathrm{O}_{3}\right)_{2}\right)+2 \mathrm{~B}_{2} \mathrm{O}_{3}+15 \mathrm{H}_{2} \mathrm{O}
\end{array}
\end{aligned}
$$

In the kinetic study, for the conversion values between 0.1 and $0.6, R^{2}$ values varied in the range of $0.9909-0.9869$ and 0.990-0.9849 in Ozawa and KAS method, respectively. Average $E_{a}$ values of Ozawa and KAS methods were calculated as $100.40 \mathrm{KJ} / \mathrm{mol}$ and $98.31 \mathrm{KJ} / \mathrm{mol}$, respectively.

In conclusion, the kinetic study of mcallisterite was reasonable considering that the Ozawa and KAS methods activation energy values were approximately the same.

\section{Conflict of Interests}

The authors declare that there is no conflict of interests regarding the publication of this paper.

\section{Acknowledgments}

The authors would like to express their deepest gratitude to Professor Dr. Sabriye Piskin and Dr. A. Seyhun Kıpçak for their contribution to the study.

\section{References}

[1] E. M. Derun, A. S. Kipcak, F. T. Senberber, and M. S. Yilmaz, "Characterization and thermal dehydration kinetics of admontite mineral hydrothermally synthesized from magnesium oxide and boric acid precursor," Research on Chemical Intermediates, 2013.

[2] E. I. Kamitsos, M. A. Karakassides, and G. D. Chryssikos, "Vibrational spectra of magnesium-sodium-borate glasses. 2.
Raman and mid-infrared investigation of the network structure," Journal of Physical Chemistry, vol. 91, no. 5, pp. 1073-1079, 1987.

[3] W. Zhu, Q. Zhang, L. Xiang et al., "Flux-assisted thermal conversion route to pore-free high crystallinity magnesium borate nanowhiskers at a relatively low temperature," Crystal Growth and Design, vol. 8, no. 8, pp. 2938-2945, 2008.

[4] M. Prokic, "Magnesium borate in TL dosimetry," Radiation Protection Dosimetry, vol. 17, no. 1-4, pp. 393-396, 1986.

[5] M. B. Piskin and H. E. Figen, "Dehydroxylation Reaction Kinetic Mechanism of İnderite Mineral," IPCBEE, vol. 10, 2011.

[6] A. K. Figen, M. S. Yilmaz, and S. Pişkin, "Structural characterization and dehydration kinetics of Kirka inderite mineral: Application of non-isothermal models," Materials Characterization, vol. 61, no. 6, pp. 640-647, 2010.

[7] W. Zhu, G. Li, Q. Zhang, L. Xiang, and S. Zhu, "Hydrothermal mass production of $\mathrm{MgBO}_{2}(\mathrm{OH})$ nanowhiskers and subsequent thermal conversion to $\mathrm{Mg}_{2} \mathrm{~B}_{2} \mathrm{O}_{5}$ nanorods for biaxially oriented polypropylene resins reinforcement," Powder Technology, vol. 203, no. 2, pp. 265-271, 2010.

[8] L. Zhihong and H. Mancheng, "Synthesis and thermochemistry of $\mathrm{MgO} \cdot 3 \mathrm{~B}_{2} \mathrm{O}_{3} \cdot 3.5 \mathrm{H}_{2} \mathrm{O}$," Thermochimica Acta, vol. 403, pp. 181$184,2003$.

[9] L. Zhihong and H. Mancheng, "Synthesis, characterization, and thermochemistry of a new form of $2 \mathrm{MgO} \cdot 3 \mathrm{~B}_{2} \mathrm{O}_{3} \cdot 17 \mathrm{H}_{2} \mathrm{O}$," Thermochimica Acta, vol. 414, no. 2, pp. 215-218, 2004.

[10] A. S. Kipcak, F. T. Senberber, E. M. Derun, and S. Piskin, "Hydrothermal synthesis of magnesium borate hydrates from $\mathrm{MgO}$ and $\mathrm{H}_{3} \mathrm{BO}_{3}$ at $80^{\circ} \mathrm{C}$," Research Bulletin of the Australian Institute of High Energetic Materials Australian Institute of High Energetic Materials, vol. 1, p. 47, 2011.

[11] A. S. Kipcak, F. T. Senberber, E. M. Derun, and S. Piskin, "Characterization of Magnesium Borate Hydrates Produced from $\mathrm{MgO}$ and $\mathrm{H}_{3} \mathrm{BO}_{3}$ at $80^{\circ} \mathrm{C}$," in Proceedings of the 12th Mediterranean Congress of Chemical Engineering, November 2011. 
[12] H. Niitsuma and T. Kikuchi, "An experimental study on the phase relations in the systems $\mathrm{MgO}-\mathrm{B}_{2} \mathrm{O}_{3}$ and $\mathrm{MgO}-\mathrm{B}_{2} \mathrm{O}_{3}$ $\mathrm{H}_{2} \mathrm{O}$," Journal of Mineralogical and Petrological Sciences, vol. 97, no. 6, pp. 285-288, 2002.

[13] C. L. Christ, "Crystal chemistry and systematic classification of hydrated borate minerals," The American Mineralogist, vol. 45, pp. 334-340.

[14] W. T. Schaller, A. C. Vlisidis, and M. E. Mrose, "Mcallisterite, $2 \mathrm{MgO} .6 \mathrm{~B}_{2} \mathrm{O}_{3} \cdot 15 \mathrm{H}_{2} \mathrm{O}$, A new hydrous magnesium borate mineral from the Death Varry reigion, Inyo Country California," The American Mineralogist, vol. 50, p. 629, 1965.

[15] Y. Zheng, Y. Tian, H. Ma et al., "Synthesis and performance study of zinc borate nanowhiskers," Colloids and Surfaces A, vol. 339, no. 1-3, pp. 178-184, 2009.

[16] W. Zhu, L. Xiang, Q. Zhang, X. Zhang, L. Hu, and S. $\mathrm{Zhu}$, "Morphology preservation and crystallinity improvement in the thermal conversion of the hydrothermal synthesized $\mathrm{MgBO}_{2}(\mathrm{OH})$ nanowhiskers to $\mathrm{Mg}_{2} \mathrm{~B}_{2} \mathrm{O}_{5}$ nanowhiskers," Journal of Crystal Growth, vol. 310, no. 18, pp. 4262-4267, 2008.

[17] W. L. Suchanek and R. E. Riman, "Hydrothermal synthesis of advanced ceramic powders," Advances in Science and Technology, vol. 45, pp. 184-193, 2006.

[18] Y. Saito, K. Kawahira, N. Yoshikawa, H. Todoroki, and S. Taniguchi, "Dehydration behavior of goethite blended with graphite by microwave heating," Journal of the Iron and Steel Institute of Japan, vol. 51, no. 6, pp. 878-883, 2011.

[19] A. K. Galwey, "Structure and order in thermal dehydrations of crystalline solids," Thermochimica Acta, vol. 355, no. 1-2, pp. 181238, 2000.

[20] S. Ener, G. Ö. Lu, and A. Demirci, "Changes in the structure of ulexite on heating," Thermochimica Acta, vol. 362, no. 1-2, pp. 107-112, 2000.

[21] M. Tunç, H. Erşahan, S. Yapici, and S. Çolak, "Dehydration kinetics of ulexite from thermogravimetric data," Journal of Thermal Analysis, vol. 48, no. 2, pp. 403-411, 1997.

[22] I. Waclawska, "Thermal behaviour of mechanically amorphized colemanite II. Internal structure reconstitution processes of ground colemanite," Journal of Thermal Analysis, vol. 48, no. 1, pp. 155-161, 1997.

[23] A. Kanturk, M. Sari, and S. Piskin, "Synthesis, crystal structure and dehydration kinetics of $\mathrm{NaB}(\mathrm{OH})_{4} \cdot 2 \mathrm{H}_{2} \mathrm{O}$," Korean Journal of Chemical Engineering, vol. 25, no. 6, pp. 1331-1337, 2008.

[24] F. Sevim, F. Demir, M. Bilen, and H. Okur, "Kinetic analysis of thermal decomposition of boric acid from thermogravimetric data," Korean Journal of Chemical Engineering, vol. 23, no. 5, pp. 736-740, 2006.

[25] Y. Guo, W. Zhang, D. Yang, and R. L. Yao, "Decomposition and oxidation of magnesium diboride," Journal of the American Ceramic Society, vol. 95, no. 2, pp. 754-759, 2012.

[26] T. Ozawa, "A new method of analyzing thermogravimetric data," Bulletin of the Chemical Society of Japan, vol. 38, no. 11, pp. 1881-1886, 1965.

[27] H. E. Kissinger, "Reaction kinetics in differential thermal analysis," Analytical Chemistry, vol. 29, no. 11, pp. 1702-1706, 1957.

[28] T. Akahira and T. Sunose, "Trans. Joint convention of four electrical institutes," Chiba Institute of Technology, vol. 16, pp. 22-31, 1971.

[29] J. Yongzhong, G. Shiyang, X. Shuping, and L. Jun, "FT-IR spectroscopy of supersaturated aqueous solutions of magnesium borate," Spectrochimica Acta A, vol. 56, no. 7, pp. 1291-1297, 2000.
[30] S. Li, D. Xu, H. Shen, J. Zhou, and Y. Fan, "Synthesis and Raman properties of magnesium borate micro/nanorods," Materials Research Bulletin, vol. 47, no. 11, pp. 3650-3653, 2012. 

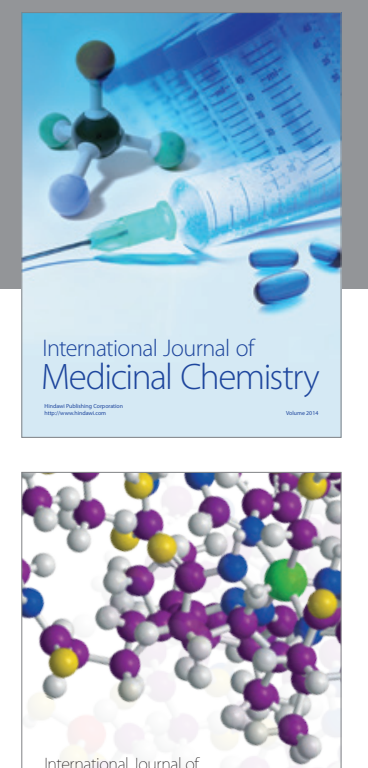

\section{Carbohydrate} Chemistry

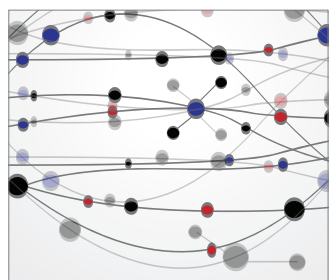

The Scientific World Journal
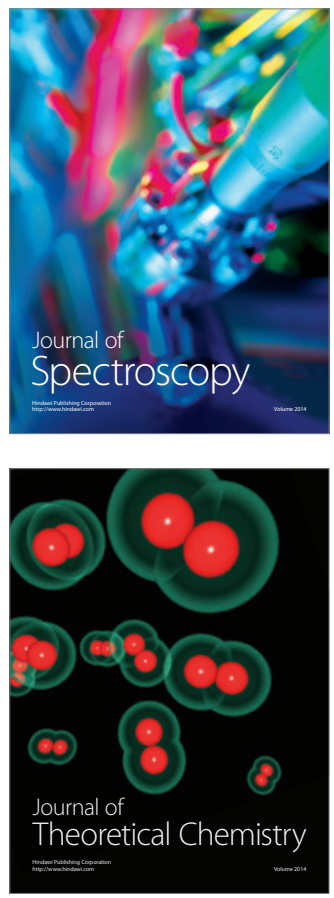
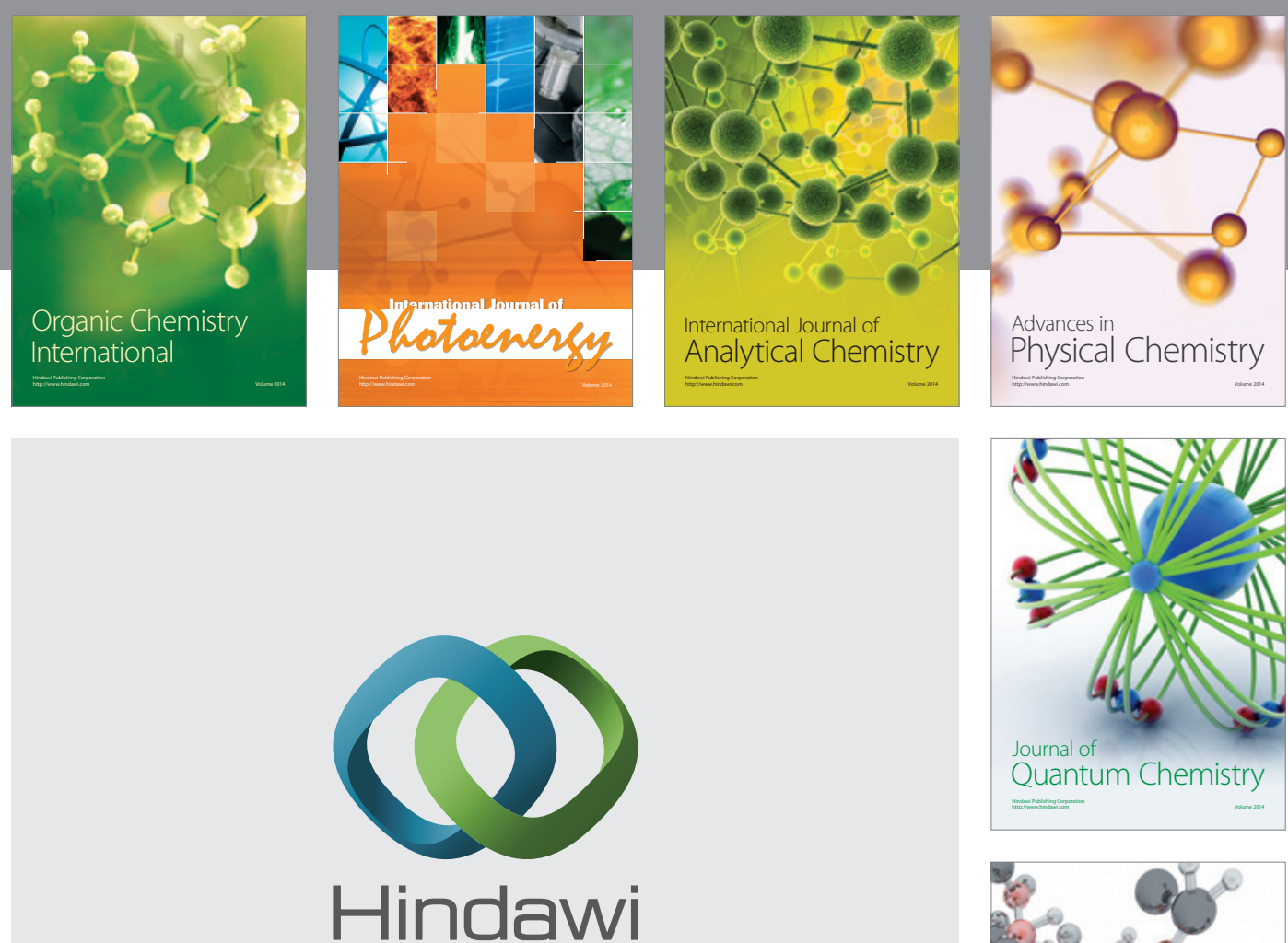

Submit your manuscripts at

http://www.hindawi.com

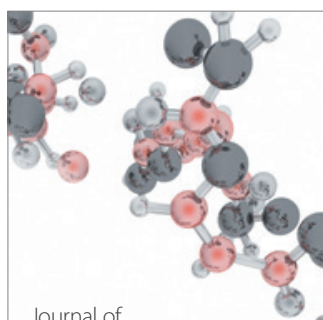

Analytical Methods

in Chemistry

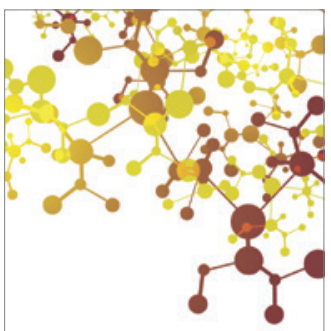

Journal of

Applied Chemistry

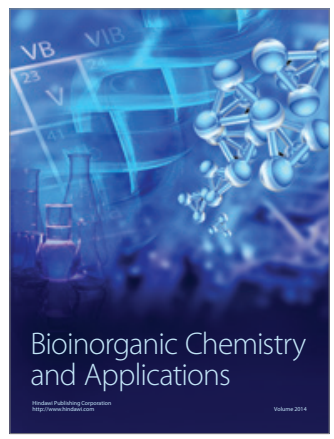

Inorganic Chemistry
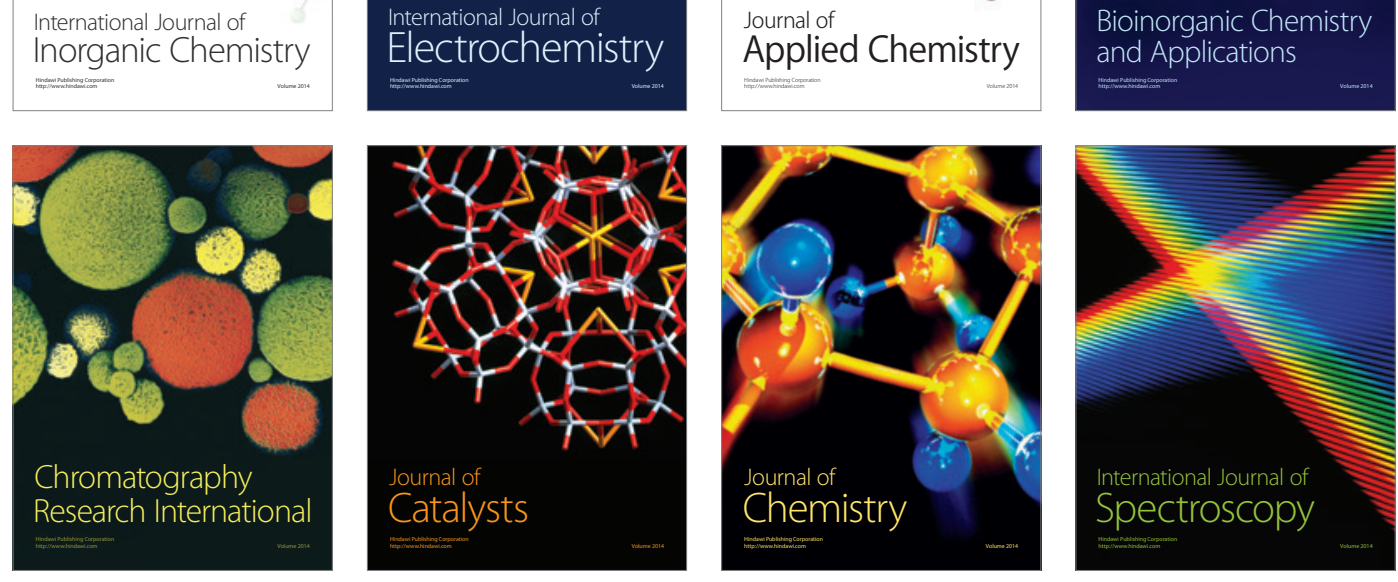